\title{
Optics education in the International Year of Astronomy
}

\section{Constance Walker, Robert Sparks, Stephen Pompea}

Constance E. Walker, Robert T. Sparks, Stephen M. Pompea, "Optics education in the International Year of Astronomy," Proc. SPIE 9665, Tenth International Topical Meeting on Education and Training in Optics and Photonics, 96650I (3 June 2007); doi: 10.1117/12.2207493

SDIE Event: Tenth International Topical Meeting on Education and Training in Optics and Photonics, 2007, Ottawa, Ontario, Canada 


\title{
Optics Education in the International Year of Astronomy
}

\author{
Constance E. Walker, Robert T. Sparks, and Stephen M. Pompea \\ National Optical Astronomy Observatory, 950 N. Cherry Ave., Tucson, Arizona, 85719 USA \\ Author Contact: Voice 520.318.8535,Email: cwalker@noao.edu
}

\begin{abstract}
:
The International Year of Astronomy (IYA) will be celebrated in 2009 to commemorate the $400^{\text {th }}$ anniversary of Galileo's first use of the telescope for astronomical observation. The National Optical Astronomy Observatory (NOAO) in Tucson, Arizona, USA, is participating in a variety of international education activities to build awareness of the role of astronomy and optics in our modern technological society. We will outline our education plans specifically related to optics for the International Year of Astronomy. These plans include outreach activities that appeal to professional museum and classroom educators as well as the general public.
\end{abstract}

\section{Introduction}

The International Year of Astronomy (IYA2009) will be a global celebration of astronomy and its contributions to society and culture, highlighted by the 400th anniversary of the first use of an astronomical telescope by Galileo Galilei. The aim of the Year is to stimulate worldwide interest, especially among young people, in astronomy and science under the central theme "The Universe, Yours to Discover". IYA2009 events and activities taking place locally, regionally, and nationally will promote a greater appreciation of the inspirational aspects of astronomy that embody an invaluable shared resource for all nations. Many organization and individuals will play a key role in these education programs. Percy (1998) highlights the key roles that amateur astronomers play in astronomy education. The program builds on partnerships such as Project ASTRO (Bennett 1998) and the European educational campaigns and programs (West 1998).

One of the primary goals of IYA2009 is to promote widespread access to the universal knowledge of fundamental science through the excitement of astronomy and sky-observing experiences. To achieve this goal, one objective will be to enable as many people as possible, especially children, to look at the sky through a telescope and gain a basic understanding of the Universe at least one time during the year. All types of events are being planned in countries across the world, which include street astronomy events, star parties, professional observatory webcasts and more. Toward that end, there are already 8 countries signed up to host 21 events. A list of planned events to date is in Table 1 at the end of this article.

\section{The US IYA Program}

In February 2007, National Optical Astronomy Observatory Associate Director for Public Affairs and Education Outreach, Douglas Isbell, was asked by the American Astronomical Society (AAS) to assume the co-chairmanship of the US International Year of Astronomy (IYA) 2009 Program Committee, along with co-chair AAS Director of Education, Susana Deustua. Shortly thereafter, a new US program outline was prepared. The goal for the US program for IYA 2009 is simple but ambitious: "To offer an engaging astronomy experience to every person in the country, and build new partnerships to sustain public interest." To fulfill the goal, six themes were created. Of the six US themes, four will be aligned around topics related to optics education.

\section{a) Looking Through a Telescope}

Star parties, sidewalk astronomy, mobile telescope vans, binocular experiences, remote telescopes, observing with a spacecraft, etc. are activities that will be encouraged in a variety of venues (observatories, science museums, nature centers, etc), so that everyone has a chance to view the wonders of the sky at least once during 2009.

Tenth International Topical Meeting on Education and Training in Optics and Photonics, edited by Marc Nantel, Proc. of SPIE Vol. 9665, 96650I · (C) 2007 SPIE, OSA, IEEE, ICO doi: $10.1117 / 12.2207493$ 
b) Telescope Building and Optics Challenges

The theme will focus on affordable telescope kits, "Hands-On Optics" activities on telescopes, related contests and internships.

c) Research Experiences for Teachers, Students and Citizen-Scientists

The research experiences encompass observing at telescopes, remote observing and image processing, data mining, work with members of NASA/ESA science teams, coordinated ground-based, space-based and amateur observing.

d) Dark Skies Are a Universal Resource

Recently, two global, citizen-scientist programs have started to heighten the awareness about the impact of artificial lighting on local environments, and the ongoing loss of a dark night sky as a natural resource for much of the world's population. Students, families and teachers all over the world participated by observing and recording the magnitude of visible stars toward the constellation, Orion, as a means of measuring light pollution in a given location. In addition, quantitative measurements of urban dark skies were taken toward zenith using digital sky-brightness meters. Using these as models for activities for IYA2009, dark sky preservation pervades areas related to optics education such as matters of stray light, light sources, shielding, vision, public health and economic issues.

In particular the science education group at the National Optical Astronomy Observatory (NOAO) in Tucson, Arizona, USA is charged with coordinating two of the working groups: Telescope Building and Optics Challenges and Dark Skies Are a Universal Resource.

\section{Telescope Building}

NOAO will be stressing educational workshops comparing Galileo's small refracting telescope to large, modern optical reflecting telescopes such as the Gemini 8-meter diameter telescope, located on Mauna Kea and in northern Chile.

The NOAO group has also developed a Hands-On Optics (HOO) kit called "Terrific Telescopes" designed for use at small science and nature centers in their outreach efforts. The kit introduces the concepts of refraction, image formation by lenses, how to build a small refracting telescope, and how to measure its performance. We will be using this kit in outreach efforts coordinated with the IYA and the Association of Science and Technology Centers (ASTC), a worldwide organization that serves hands-on science centers. This kit represents a cost-effective teaching tool that covers the basics of image formation using lenses and mirrors, and also gives the participants "make and take" telescopes.

Key design issues for an affordable telescope that both the USbased and international-based working groups are pondering at the moment are:

- Should the telescope resemble the one Galileo used to look toward the heavens?

- Should there be an affordable kit for reflecting telescopes in addition to one for refractors?

- Should the image formed by the telescope be right-side up for use by students in classrooms or upside-down as with telescopes used in astronomical settings?

- Should there be a mount for each telescope? (To some, stability is a concern.)

- Should the telescopes be pre-produced, assembled and distributed or be in affordable, easy and ready-to-build kits?

- What power is needed to resolve things? Is $10 \mathrm{x}$ to little? Is $40 \mathrm{x}$ too much? Is $30 \mathrm{x}$ the right amount? 
At present, one of the most affordable, unassembled telescope kit on the market is the Project STAR refracting telescope kit. This simple kit enables students to build a 16-power refracting similar to Galileo's. Students can use the telescope to see how it is similar to a pinhole camera, to view inverted astronomical images, to estimate the magnification power, to find the focal length of a lens and to see how the moon looked to Galileo. The Kit includes ( 10 of each unless noted): inner and outer tubes; plastic lenses ( $43 \mathrm{~mm}$ diameter, objective, $400 \mathrm{~mm}$ focal length); plastic lenses (17.5 $\mathrm{mm}$ diameter, $25 \mathrm{~mm}$ focal length); foam holders, cardboard spacers and washers for the eyepiece lenses; red plastic caps; 1 set of instructions and activities. A set of 10 telescopes costs $\$ 50.00$.

How do you teach about telescopes?

In teaching about the optics of telescopes, NOAO's Hands-on Optics "Terrific Telescopes" module starts students off with an activity that investigates how light bends. Students explore ideas through hands-on experiences, formulate and test hypotheses, solve problems, and create explanations for what they observe. Through multiple activities they build a refracting telescope and measure its resolution. There are formative assessment opportunities throughout the module to gauge student comprehension. This module follows a "Learning Cycle" framework (exploration, concept introduction, concept application); however, it can be adjusted to follow the learning style framework that best fits the target audience.

Here the key activities in the "Terrific Telescopes" kit are discussed in the order in which the students experience them:

Light Through an Acrylic Block: A Demonstration: 10-15 minutes

Starting with a laser shining at normal incidence to an acrylic block, the teacher will slowly increase the incident angle. The students will observe that the path of the light changes as the incident angle increases.

Light Passing Through a Convex Lens : A Demonstration : 15-

\section{0 minutes}

When parallel light beams encounter an object such as a lens, its shape can cause different light rays to bend by different amounts. Students predict the path of the rays through an acrylic block and through a lens, then determine if they are correct by using a mister or chalk dust to expose the laser beams.

Finding the Focal Length Using a Distant Object: $30-40$ $\underline{\text { minutes }}$

When looking at a brightly colored lamp on one side of the room, students will measure the focal length of a lens by forming an image of the light on a screen and measuring the distance between the lens and the screen.

Simple Magnifiers: $30-40$ minutes

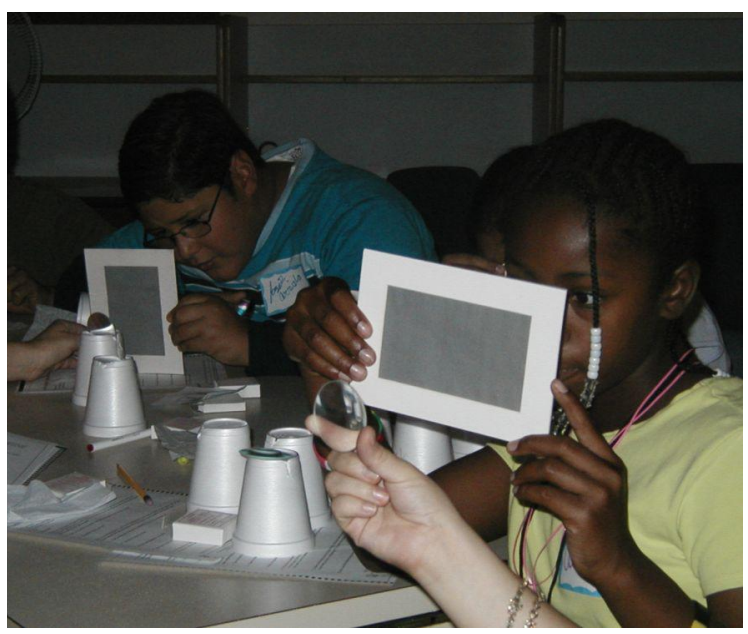

In this activity, students will explore the magnifying properties of the lenses and notice the connection between how much the lens is curved and its ability to magnify. The students can also see how a juice bottle filled with water can be used as a magnifier as well.

Build a Refracting Telescope I: $30-40$ minutes

This is the first of several activities relating to refracting telescopes. Students will first determine how to arrange two lenses so that when they look though them they will see a magnified image of a distant object.

\section{Build a Refracting Telescope II: $30-40$ minutes}

Using the configuration of lenses that they found previously, students will create a magnified image of a distant object. By placing the velum screen in varying locations, students will determine the function of each lens in a basic refracting telescope.

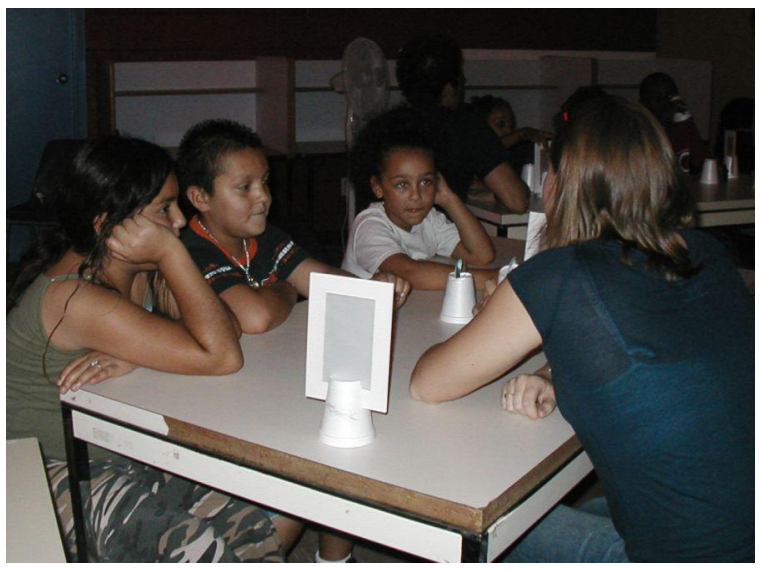


Build a Refracting Telescope III: 20-30 minutes

The students in groups of two or three will build the refracting telescope from the kit. They will then look through the telescope at distant objects, making notes about their observations.

A Measure of Resolution: 30-40 minutes

Using the telescopes from the previous activity, students will make and graph measurements to compare the telescope's resolution with that of their eye. Additional options include the comparison of the telescope's measured resolution to its theoretical resolution.

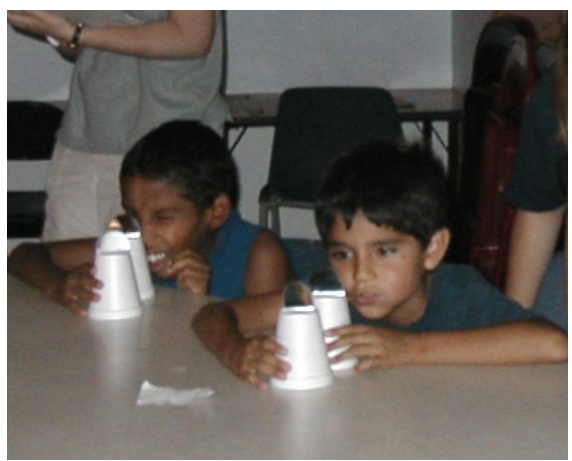

Build a Three-Lens Refracting Telescope: An Activity for Student Assessment: 50-60 minutes

What happens to a telescope's image when a third lens is added to the system? Students will find that a third lens creates an upright image and will draw the optical layout of such a system.

Once a student has gone through the "Terrific Telescopes" kit, she will learn:

- In a uniform medium, light will travel in a straight path.

- When light hits a boundary between two different substances, such as air and water, the path it follows can change.

- A convex lens can cause parallel rays of light to converge.

- The point at which parallel light rays meet after passing through a lens is called the focal point.

- The distance from the lens to the point where the light rays meet is called the focal length.

- Converging lenses can be used to project an inverted image onto a screen.

- Converging lenses can be used to magnify an object.

- The amount of magnification is related to the focal length of the lens.

- The point at which an image "flips" is the focal point.

- Focusing is done by adjusting the distance between the

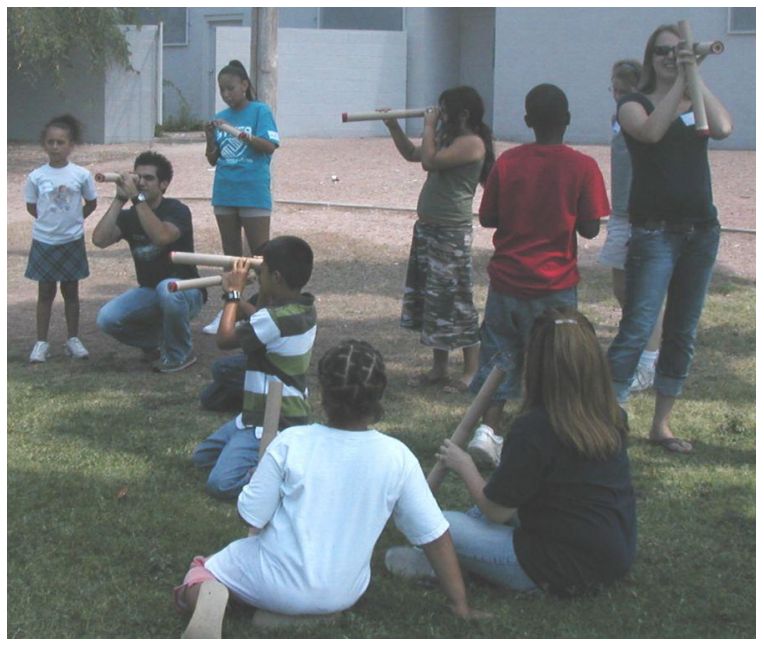
two lenses.

- To achieve the greatest magnification, the most curved lens (shortest focal length) is the 1 closest to the eye.

- The two-lens system will invert the image.

- The first lens creates an inverted, real image on the screen.

- The second lens acts as a simple magnifier, making the image larger.

- How to assemble a simple refracting telescope.

- How to estimate the magnification of a refracting telescope.

- Resolution is a measure of how much detail can be observed.

- How to determine the resolution of objects.

\section{Optics Challenges}

Optics challenges for IYA2009 could come in many forms; there are optics challenges that could be designed for museums, schools, Boys and Girls Clubs, other community centers, astronomy clubs, career days, camps, science festivals, optical societies, teacher professional development workshops at local and national levels (e.g., National Science Teacher Association meetings) and events like MESA Day competitions. (MESA stands for "Math Engineering Science Achievement" program and serves underrepresented students.) NOAO has hosted optics challenges in all of these venues. These events are an important part of our outreach to the community, and may serve as some of the ideas for IYA. As the basis for these challenges, NOAO has used many of the assessment activities in its six modules, in particular, the "Hit the Target" optics challenge from Module 1. In other cases, challenges have developed as a result of modules, such as the telescope competition from Module 3. Success of their application to events for IYA will rely on the adaptability of these challenges to satisfy a broader age range. 
Here are a few examples of optics challenges hosted by NOAO:

"MESA Day" Telescope Competition

From 2004-2006, we partnered with the MESA Program in Arizona to host a "Build a Reflecting Telescope" competition in conjunction with the statewide MESA Day competitions. Students at each school were given a primary mirror, secondary mirror, and an eyepiece. Students had to design and test the telescope using these optical components. The telescope was judged on its design as well as its resolution. In 2006, 14 middle school and 9 high school teams entered telescopes in the competition. A survey of the teams revealed they spent an average of 16 hours per student on the telescope. Teams consisted of 3-4 students.

\section{"MESA Day" Hit the Target Competition}

Arizona MESA wanted to try a different competition for 2007. We decided to use a slightly modified version of "Hit the Target" from Module 1. Each team was given a kit containing a laser, several mirrors, a target, rulers, string and a protractor to practice before the competition. The middle school competition consisted of two rounds. Students had to bounce the laser off of two mirrors in the first round and three mirrors in the second round. The High school competition added a third round. In the third round, they chose how many mirrors to use. They could use from 3-6 mirrors and would score more points for using more mirrors. In 2007, a total of 37 teams entered the state competition. The competition was judged by trained NOAO student workers and staff.

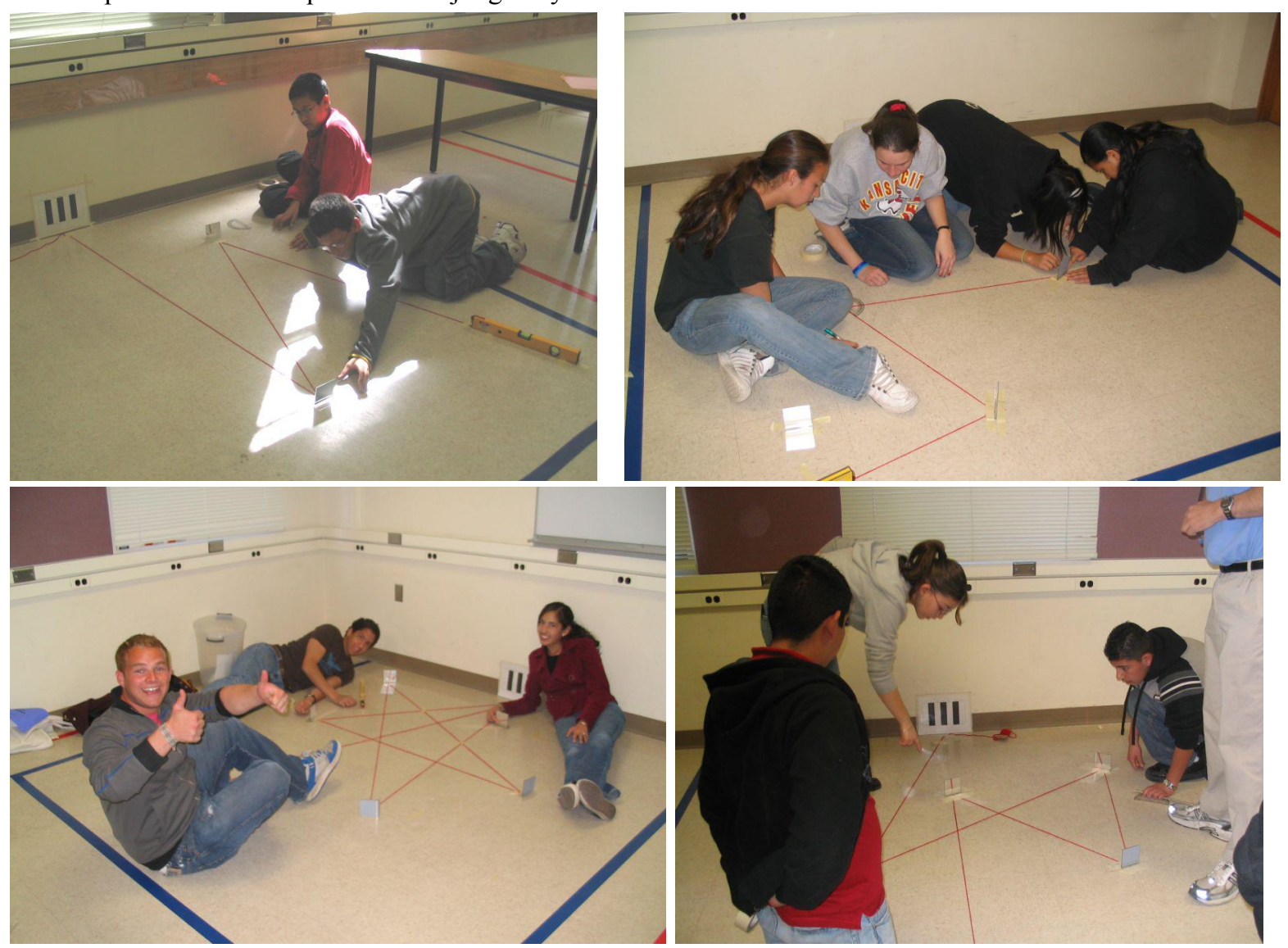

St. Michael's School Optics Competition

St. Michael's School in Tucson has hosted a Tucson city-wide optics festival the last two years in conjunction with their science fair. The Optics Festival is held in mid-February after school. We set up several booths around the gym where students engaged in optics activities including exploring optical illusions, building kaleidoscopes, learning about luminescence, and learning about polarization of light. The festival also has a "Hit the Target" competition for fifth and sixth grade students. 40 teams of 2 students each participated in the competition in 2007. Prizes are donated by the school and NOAO including the grand prize, a pair of video iPods for the winning team. The St. Michael's Optics Festival attracted about 150 people in 2007 including students and parents. 


\section{Dark Skies Are a Universal Resource}

There is a lot more optics education in a recent global campaign on preservation of dark skies than initially meets the eye. For a second year in a row the GLOBE at Night campaign (sponsored by NOAO and GLOBE) was held for two weeks in March. Students, families and teachers all over the world participated by observing and recording the magnitude of visible stars toward the constellation, Orion, as a means of measuring light pollution in a given location. The number of unaided eye observations increased from almost 4600 in March 2006 to almost 8600 in March 2007. This year's campaign took on a new twist to obtain precise measurements of urban dark skies toward zenith using digital sky-brightness meters. NOAO received funding to buy and distribute 135 Unihedron Sky Quality Meters to educators, students, amateur astronomers, professional astronomers, science museum staff, and IDA members in 21 U.S. states, the Washington, DC area, major observatories and five other countries. Kits for teaching about light pollution, designed and built by NOAO, were also distributed along with the brightness meters to the same sites. Both flavors of the program were designed to heighten the awareness about the impact of artificial lighting on local environments, and the ongoing loss of a dark night sky as a natural resource for much of the world's population.
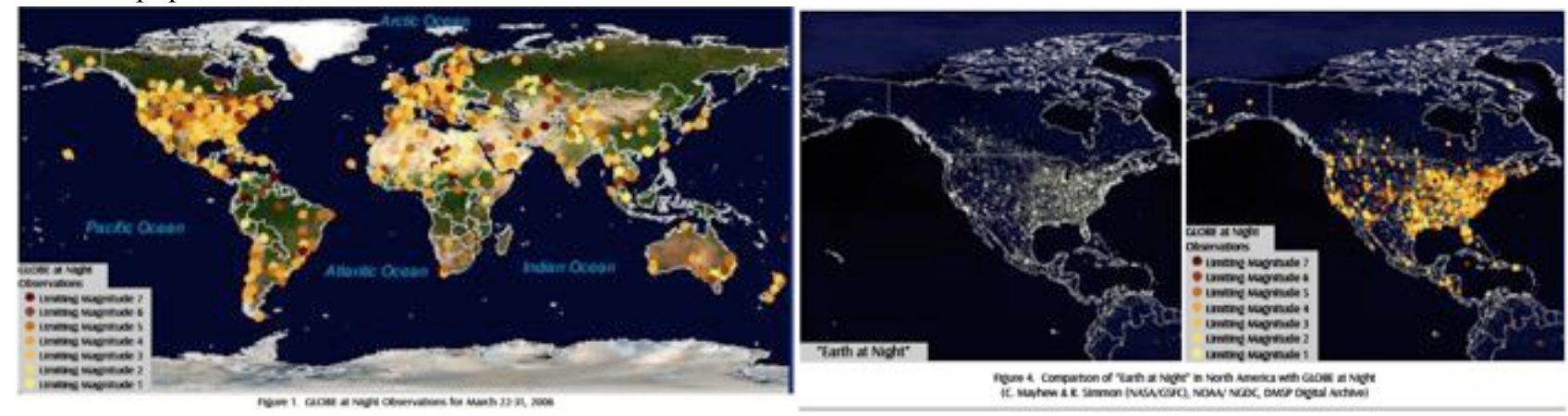

Light pollution is the illumination of the night sky caused by artificial light sources on the ground (streetlights, billboards, etc.). Both the light and the loss of contrast make it difficult to find fainter stars and nebulae. The amount of outdoor lighting increases as a result of increasing population. As cities and suburban areas grow, the number of lights at night also increases. Lights, contrast, and glare all impact the number of stars that are visible in a given location. Outdoor lighting is used for many reasons including security, sporting events, and advertising. Some outdoor lighting is more efficient in its design and/or placement and limits the amount of light shining up or away from the intended purpose. Using lights at night can be helpful, but there are trade-offs in the form of unanticipated effects. Lights at night can impact both the biology and ecology of species in the wild, such as the disorientation of sea turtle hatchlings by beachfront lighting. Light pollution can cause adverse effects to humans as well as the ecosystem, or to anywhere in the nighttime environment. These effects include glare, compromised visibility and vision, interruptions in the human circadian rhythm, visual clutter and confusion, energy waste, light trespass, and sky glow.

Two elements of light pollution affect astronomers most: skyglow and light trespass. Skyglow is a result of fixtures, which emit a portion of their light directly upward into the sky where the light scatters, creating an orange-yellow glow above a city or town. This light can then interfere with sensitive astronomical instruments trying to capture light from distant galaxies. Light trespass occurs when poorly shielded or poorly aimed fixtures cast light into unwanted areas, such as observatory and buildings. This light also interferes with astronomical instruments. What can be done: use fully shielded light fixtures, those which put light only where it is wanted and needed, not up into the sky where it is useless, or onto neighboring properties where it will affect others. Also, certain light sources are more 'astronomically friendly' than others. Low Pressure Sodium (LPS) lights are preferable near observatories, whereas Metal Halides are less preferable.

Optics education pervades many areas of life. The GLOBE at Night campaign and other potential "Dark Skies are a Universal Resource" activities are among those areas. The success of GLOBE at Night 2007 is a major step toward the International Year of Astronomy in 2009, when one goal is to make the digital data collection into a worldwide activity. 
Future Plans for GLOBE at Night and the SQMS

With more than 135 hand-held devices called "Sky Quality Meters" (SQMs) distributed to dozens of sites, mainly in the US but also in a few other countries, hundreds of SQM measurements at GPS-referenced points across towns and out into the countryside were made this March. This included taking multiple readings in different places (e.g. along a diameter across a town) and perhaps at different times (e.g. before and after lighting curfews). If this work is to have a lasting value and continue into the years to come, filter and sensor calibration are still issues to be resolved. For astronomy, such measurements in and around and on observatory mountain tops can potentially help in the refinement of feedback for astronomers and government authorities on the effects of relevant environmental (light-pollution) legislation and lighting codes in controlling the outward creep of light pollution, especially in areas around observatories. But it is also the dark sites in urban areas that we should identify and preserve.

The SQM program worked very well in 2007 at recruiting the interest and heightening the awareness of citizenscientists and forming an initial database of sky brightness measurements. We are forming plans to expand that part of the program in 2008, perhaps adding more sophisticated (more stable?) web-linked meters being developed by Dan McKenna at the University of Arizona - and then decide more specifically how to play our part in the IYA in 2009.

Table 1. National and Global Activities for IYA related to optics education

\begin{tabular}{|c|c|c|c|c|}
\hline Activity Name & Activity Description & $\begin{array}{l}\text { National } \\
\text { or Global }\end{array}$ & $\begin{array}{l}\text { Contact } \\
\text { Person } \\
\end{array}$ & Email Address \\
\hline $\begin{array}{l}\text { Moons of Jupiter } \\
\text { and small } \\
\text { telescopes }\end{array}$ & $\begin{array}{l}\text { Try to produce and distribute } \\
\text { Galilean refractors for the } \\
\text { observation of the Moons of } \\
\text { Jupiter }\end{array}$ & Brazil & $\begin{array}{l}\text { Dr. Augusto } \\
\text { Damineli }\end{array}$ & $\begin{array}{l}\text { daminieli@astro.iag.usp.b } \\
\mathrm{r}\end{array}$ \\
\hline Galileo Did It & $\begin{array}{l}\text { To make } 1 \text { million Canadians to } \\
\text { look through a telescope }\end{array}$ & Canada & Dr. Hesser & Hesser@nrc-cnrc.gc.ca \\
\hline $\begin{array}{l}\text { Astronomy at the } \\
\text { Telescope 1609- } \\
2009\end{array}$ & $\begin{array}{l}\text { Conference that will stress the } \\
\text { discoveries made via telescopic } \\
\text { observations (starting with } \\
\text { Galileo) } \\
\text { 1-4 Jan, } 2009\end{array}$ & $\begin{array}{l}\text { Hawaii, } \\
\text { USA }\end{array}$ & $\begin{array}{l}\text { Dr. Russell } \\
\text { M. Genet }\end{array}$ & russmgenet@aol.com \\
\hline $\begin{array}{l}\text { Astronomy in the } \\
\text { Italian Shopping } \\
\text { Centers }\end{array}$ & $\begin{array}{l}\text { To use the shopping malls in Italy } \\
\text { to promote astronomy }\end{array}$ & Italy & $\begin{array}{l}\text { Dr. } \\
\text { Leopoldo } \\
\text { Benacchio }\end{array}$ & benacchio@inaf.it \\
\hline $\begin{array}{l}\text { Faulkes } \\
\text { Telescope Irish } \\
\text { Competition }\end{array}$ & $\begin{array}{l}\text { For schools, graduate students, } \\
\text { postdocs, staff }\end{array}$ & Ireland & $\begin{array}{l}\text { Dr. Michael } \\
\text { Redfern }\end{array}$ & redfern@nuigalway.ie \\
\hline Astro-Fest & $\begin{array}{l}\text { Stargazing, lectures, concerts, } \\
\text { 400th telescope fest, exhibition } \\
\text { tour of telescopes, school for } \\
\text { teachers, distribution of materials }\end{array}$ & $\begin{array}{l}\text { South } \\
\text { Korea }\end{array}$ & $\begin{array}{l}\text { Dr. Young- } \\
\text { Soo Kim }\end{array}$ & ykim@kasi.re.kr \\
\hline $\begin{array}{l}\text { Summer } \\
\text { Astronomy in } \\
\text { Portugal }\end{array}$ & $\begin{array}{l}\text { People are invited to observe the } \\
\text { Sun and Night Sky. Involves } \\
\text { hundreds of sessions, using small } \\
\text { telescopes and observatories. }\end{array}$ & Portugal & $\begin{array}{l}\text { Dr. António } \\
\text { Pedrosa }\end{array}$ & apedrosa@multimeios.pt \\
\hline $\begin{array}{l}\text { Moon Week } \\
\text { 2009, Thomas } \\
\text { Harriot's } \\
\text { celebrations }\end{array}$ & $\begin{array}{l}\text { Observe the Moon and Saturn, } \\
\text { coincide with the 400th } \\
\text { anniversary of Thomas Harriott } \\
\text { observations of the Moon in July } \\
1609 \text {, events at Syon House. } \\
\text { (Thomas Harriot's observations of } \\
\text { August } 1609 \text { and subsequently } \\
\text { may have been the first uses of } \\
\text { telescopes for astronomy) July'09 }\end{array}$ & UK & $\begin{array}{l}\text { Prof. Ian } \\
\text { Robson }\end{array}$ & eir@roe.ac.uk \\
\hline
\end{tabular}




\begin{tabular}{|c|c|c|c|c|}
\hline $\begin{array}{l}\text { A telescope in } \\
\text { every secondary } \\
\text { school }\end{array}$ & Ambitious and complex & UK & $\begin{array}{l}\text { Prof. Ian } \\
\text { Robson }\end{array}$ & eir@roe.ac.uk \\
\hline $\begin{array}{l}\text { Card Telescopes } \\
\text { for museums/ } \\
\text { planetaria/VCs }\end{array}$ & & UK & $\begin{array}{l}\text { Prof. Ian } \\
\text { Robson }\end{array}$ & eir@roe.ac.uk \\
\hline $\begin{array}{l}\text { Looking through } \\
\text { a telescope }\end{array}$ & $\begin{array}{l}\text { Star parties, sidewalk astronomy, } \\
\text { mobile telescope vans, binocular } \\
\text { experiences, remote telescopes, } \\
\text { observing with a spacecraft }\end{array}$ & USA & Doug Isbell & disbell@noao.edu \\
\hline $\begin{array}{l}\text { Research } \\
\text { experiences for } \\
\text { students, } \\
\text { teachers, and } \\
\text { citizen-scientists }\end{array}$ & $\begin{array}{l}\text { Observing at telescopes, remote } \\
\text { observing and image processing, } \\
\text { data mining, work with members } \\
\text { of NASA/ESA science teams, } \\
\text { coordinated ground-space- } \\
\text { amateur observing }\end{array}$ & USA & Doug Isbell & disbell@noao.edu \\
\hline $\begin{array}{l}\text { Telescope } \\
\text { building and } \\
\text { Optics } \\
\text { Challenges }\end{array}$ & $\begin{array}{l}\text { "Telescope amnesty", new } \\
\text { telescope kits, Hands-On Optics, } \\
\text { Contests and Science Festivals, } \\
\text { Internships with big telescope } \\
\text { projects }\end{array}$ & USA & Doug Isbell & disbell@noao.edu \\
\hline $\begin{array}{l}\text { The Quest to See } \\
\text { Infinity: 400th } \\
\text { Anniversary of } \\
\text { the Telescope }\end{array}$ & TV program, documentary & USA & $\begin{array}{l}\text { Richard } \\
\text { Hudson }\end{array}$ & rhudson@tpt.org \\
\hline $\begin{array}{l}400 \text { Years of the } \\
\text { Telescope }\end{array}$ & $\begin{array}{l}\text { TV program entitled "400 Years } \\
\text { of the Telescope: A Journey of } \\
\text { Science, Technology, and } \\
\text { Thought" }\end{array}$ & USA & Kris Koenig & $\begin{array}{l}\text { kris@interstellarstudios.c } \\
\text { om }\end{array}$ \\
\hline Globe at Night & $\begin{array}{l}\text { To draw attention to the light } \\
\text { pollution without having to get } \\
\text { into politically charged issues of } \\
\text { safety and security. }\end{array}$ & Global & Doug Isbell & disbell@noao.edu \\
\hline Light Pollution & $\begin{array}{l}\text { Awareness on the problems } \\
\text { created by light pollution }\end{array}$ & Global & Bob Crelin & bob@bobcrelin.com \\
\hline $\begin{array}{l}\text { Sidewalk } \\
\text { Astronomy }\end{array}$ & $\begin{array}{l}\text { Give as many people as possible } \\
\text { the chance to look through a } \\
\text { telescope }\end{array}$ & Global & $\begin{array}{l}\text { Dr. Rick } \\
\text { Fienberg }\end{array}$ & $\begin{array}{l}\text { rfienberg@skyandtelesco } \\
\text { pe.com }\end{array}$ \\
\hline $\begin{array}{l}\text { Activities for } \\
\text { small telescopes }\end{array}$ & $\begin{array}{l}\text { To prepare activities to use the } \\
\text { small telescopes }\end{array}$ & Global & $\begin{array}{l}\text { Dr. Rick } \\
\text { Fienberg }\end{array}$ & $\begin{array}{l}\text { rfienberg@skyandtelesco } \\
\text { pe.com }\end{array}$ \\
\hline $\begin{array}{l}\text { Track Galileo's } \\
\text { Observations }\end{array}$ & $\begin{array}{l}\text { On January } 101610 \text { Galileo } \\
\text { pointed his telescope at the sky } \\
\text { and made interesting discoveries. }\end{array}$ & Global & & \\
\hline $\begin{array}{l}\text { Does Venus go } \\
\text { around the Sun? }\end{array}$ & $\begin{array}{l}\text { By using small telescopes, always } \\
\text { under the same magnification of } \\
\text { around } 60 \mathrm{X} \text {, follow the phases } \\
\text { and apparent sizes of Venus from } \\
\text { January to July, 2009. Each time, } \\
\text { estimate the angular separation } \\
\text { between Venus and the Sun. Then } \\
\text { make a sketch showing the } \\
\text { positions of Venus with respect to } \\
\text { the Sun and the Earth every two } \\
\text { weeks. Compare your results with } \\
\text { Galileo's. Was Copernicus right? } \\
\text { From Jan to Jul } 2009\end{array}$ & Global & $\begin{array}{l}\text { Francisco } \\
\text { Diego }\end{array}$ & fd@star.ucl.ac.uk \\
\hline
\end{tabular}




\begin{tabular}{|c|c|c|c|c|}
\hline $\begin{array}{l}\text { Calculate the } \\
\text { speed of light by } \\
\text { observing the } \\
\text { moons of Jupiter }\end{array}$ & $\begin{array}{l}\text { To reproduce the observations by } \\
\text { Olaus Roemer who, using a small } \\
\text { telescope, could calculate the } \\
\text { speed of light by timing the } \\
\text { motions of the moons of Jupiter } \\
\text { discovered by Galileo nearly } 70 \\
\text { years earlier. } \\
\text { From mid Mar } 2009 \text { to mid Jan } \\
2010\end{array}$ & Global & $\begin{array}{l}\text { Francisco } \\
\text { Diego }\end{array}$ & fd@star.ucl.ac.uk \\
\hline
\end{tabular}

\section{Conclusion}

The International Year of Astronomy provides a powerful organizing force for optics education. Given the importance of telescopes to astronomy education and to teaching optics, IYA activities in this area will be of particular value to both fields. The wealth of activities coupled with the worldwide scope of the program will make for an exciting anniversary for the telescope.

\section{References}

J. R. Percy, “The Role of Amateur Astronomer in Astronomy Education”, New Trends in Astronomy Teaching, edited by L. Gouguenheim, D. McNally, and J. R. Percy, Cambridge University Press, (1998).

R. M. West, “Current Trends in European Astronomy Education”, New Trends in Astronomy Teaching, edited by L. Gouguenheim, D. McNally, and J. R. Percy, Cambridge University Press, (1998).

M. Bennett, A. Fraknoi, and L. Richter, Project ASTRO: A Successful Model for Astronomer/Teacher Partnerships", New Trends in Astronomy Teaching, edited by L. Gouguenheim, D. McNally, and J. R. Percy, Cambridge University Press, (1998). 